\title{
РЕКОНСТРУКЦІЯ ОСОБИСТІСНОЇ ІДЕНТИЧНОСТІ В ПРОЦЕСАХ ІНФОРМАЦИЙНОГО ОБМІНУ В УМОВАХ СУСПІЛЬНИХ ТРАНСФОРМАЦІЙ
}

\begin{abstract}
Обстоюється думка, що в середовищі сучасних процесів, які впливають на визначення особистісної ідентичності, велику вагу має простір масової комунікації. Звертається увага на те, що в цьому просторі місце друкованих засобів поступово займає інтернет, а радіо й телебачення за впливом на коло спілкування і духовний світ людини, хоч i досі посідають перші місця, але суттєво змінюють свої методи й засоби впливу. Стверджується, що протидіяти зовнішньому тиску істотно допомагають ефективні комунікативні зв'язки: саме завдяки глибокому корінню ідентичності особистість зберігає надійний зв'язок між сутнісними пластами свого “Я”. Наголошується, що сам характер спілкування та його розвиток значною мірою залежать від інтересів особистості і тих інформаційних потреб, які задовольняє зміст матеріалів мас-медіа. Зауважено також, що не меншу роль у цьому процесі відіграє усвідомлення людиною особистісної ідентичності та рівень культури споживання продукції масової комунікації.

Ключові слова: особистість, ідентичність, мас-медіа, інформаційний простір, психологічні якості, трансформація.
\end{abstract}

Постановка проблеми. Якщо оглянути увесь сучасний набуток спеціальних галузей як психології, так і соціології, що зосереджуються на предметі ідентичності та персоніфікації особистості в середовищі масової комунікації, то відчувається певний внутрішній дисонанс між розумінням глибини процесів і змін, що відбуваються, і поясненням цих змін у некласичному й постнекласичному ключі соціопсихологічної та соціокомунікативної теорії.

Невирішеною частиною загальної проблеми тут виявляється лише часткова (переважно соціологічна) інтерпретація активізації гібридних впливів мас-медій в умовах різкої поляризації думок і позицій особистості в суспільстві. При цьому будь-яка чиста теоретизація в цьому напрямі не може бути вичерпною, адже ані психологічні теоретизації щодо трактування сутності ідентичності, ані макро- і мікросоціологічні піходи, що домінують у вивченні ефектів масових комунікацій у методиках поточних досліджень медіакомунікації, не можуть дати всеохопної картини трансформацій, що відбуваються в сучасному інфрмаційному просторі.

Meта статmі: аналіз та інтерпретація процесів самовизначення особистістю своєї ідентичності, їі реконструкція в разі певних деформацій, які виникають під впливом кризових явищ дійсності та засобів масової комунікації, що активно діють в інформаційному просторі. 
Аналіз останніх досліджень $і$ публікацій. Протягом останніх 20 років, які прийшлися на перетин століть, простежується досить явна тенденція до виокремлення комунікативної дії й особи діяча (“actor" за Ю. Габермасом), а також агентної (представницької) ролі мас-медій щодо подання картини світу (“agency”) [9]. Тут варто було б згадати твердження Н. Лумана, який, виступаючи проти поширеного тоді в соціальних науках помилкового бачення, наголошував, “що ані дії, ані дійові особи не даються нам у вигляді емпіричних фактів. Адже межі (а значить, і єдність) дії та дійової особи не можна ні побачити, ні почути" $[4$, с. 55]. Розвиваючи думку Лумана, можна констатувати, що одним з надійних критеріїв для оцінювання ролі масової комунікації в процесі становлення особистості $\epsilon$ iï розвиток і розширення спектру іiі інтересів, спрямованість особистості на приймання інформації різних типів і тематики (суспільно-політичної і художньої, пізнавальної і розважальної тощо), оскільки це свідчить про соціальну активність особистості та усвідомлення нею своєї соиіокультурної (у тому числі етнокультурної) і національної ідентичності.

Останнім часом 3'явилося чимало публікацій, автори яких намагаються “об’єктивізувати” процес легітимації національної ідентичності та пояснити більш-менш наближено до істини, чому й досі ми не пережили, не подолали тих наслідків тоталітарної свідомості, які явно гальмують усі скільки-небудь сучасні й прогресивно-цивілізаційні ідеї і реальні кроки до їх утілення. Часто в цих публікаціях можна побачити щось більше схоже на “самовираження", ніж справжній аналіз можливих причин та наслідків такого стану речей. Начебто сама незалежність була першим і останнім із цих кроків до загальносвітової цивілізації. Сравжніми поборниками викристалізовування національної ідентичності можна вважати таких провідників ідеї незалежності України, як В. Брюховецький, Є. Сверстюк, В. Скуратівський, М. Слюсаревський та ін. Аналіз поглядів цих відомих оборонців ідеї української незалежності наведено в одній 3 моїх статей [7], де зазначається, що сьогоднішній, поширений нині в Україні, тип людини бачиться їм як “тип людини без Бога, без святинь, без національної гідності, без народних традицій і великих принципів, які ставляться вище користі”. Це, власне, тип корисливого споживача, який наперед погоджується 3 керівною лінією, але не погоджується ступити хоч один крок задля громадського добра коштом власної користі [там само, с. 108-109].

Рідкісним винятком, на жаль, можна вважати психологічно виважений аналіз, чому відбулися ті чи ті масові виступи, ті чи ті зрушення у свідомості мас, або ж замітки чи статті справді аналітичнооб'єктивного спрямування. Такий аналіз здебільшого продукований людьми, які так чи інакше були пов'язані з політикою в минулому або деякою мірою включені в сьогоденне політикотворення. Навіть на 
хвилі Майдану до керівництва просвітницько-політичними процесами не прийшли фахівці (особливо це стосується сфер мас-медійного ринку, де ринкові умови значною мірою витіснили й далі витісняють справжніх журналістів - фахівців своєї справи).

Розглядаючи відповідно до психологічних традицій сучасні зміни мас-медійного дискурсу в тренді соціометрії Дж. Морено як "науки про суспільство", можна констатувати деякі неактивно впливові, але досить значущі моменти та прийоми, що застосовуються для того, щоб ускладнити сприймання цілісної картини та узагальнених проблем суспільного значення. Мультиплікованість, дискретність і дріб'язковість стали типовими прийомами в подання матеріалів електронними засобами мас-медій, включаючи дифамаційну сутність більшості текстів або "постів" (у соціальних інтернет-мережах). Останні поступово займають місце офіційної суспільної думки, часто-густо заступаючи собою об'єктивну інформацію [8]. Гібридизація інформаційного простору, маніпулювання "всіма і вся" також породжують невпевненість, особливо беручи до уваги те, що, за словами Романа Чайки, ведучого токшоу “Клуб реформ" на "5-му каналі”, “досягання аудиторії через телебачення страшенно впало порівняно з тим, який вплив телебачення мало ще п'ять років тому" [3]. Серед найважливіших подій минулого політсезону Р. Чайка відмітив: “остаточний вихід усіх так званих експатів-реформаторів: завершення грузинської команди, i потім усіх інших. Дуже важко працювати з людьми, яким апріорі видавався картбланш і які вважаються супер-пупер-реформаторами, зірками; оскільки в нас міністри - політичні фігури, до них було дуже важко добиратися, в плані отримання об'єктивної, критичної інформації' [там само]. Беручи до уваги соціальні ролі в малих групах, можна спробувати проаналізувати взаємодію соціальних інститутів та їхніх організацій (зокрема політичних), оцінити їхню потенційну спроможність/ неспроможність виконувати ті чи інші суспільно-політичні функції. 3 огляду на сучасний владно-структурний і політичний спектр України зауважимо, що й до сьогодні в державі немає реальних, дієвих політичних сил, які б ставили у своїх програмах і відтак вирішували завдання легітимації національної ідентичності в національному масштабі і на рівні спільнот, які проживають на території України.

Якщо розглядати процес легітимації як трискладовий, або триступеневий, неважко побачити, що фактори, значущість яких висока (тобто які можна вважати такими, що задають норми поведінки), відображатимуть водночас і соцієтальні, і психологічні аспекти:

соиієтальні: 1) формальна підпорядкованість поведінки соціальному порядку, законам країни; 2) афективність комунікативних дій; 3) ціннісна раціональність дій; 4) релігійність/атеїстичність; 
психологічні: 1) хиткість атитюдів; 2) цілераціональність діяльності; 3 ) традиційність/нетрадиційність учинків.

Остання якість (релігійність/атеїстичність) у ряді соцієтальних аспектів віддзеркалює непорушний порядок цілей і цінностей. Це, до речі, помітив ще М. Вебер, який стверджував, що власна значущість людини завжди підкріплена вірою. На думку Дж. Александера, такій людині властива також більша стабільність, зокрема в поведінці, адже вона визначається не лише цілераціональними мотивами [1], тому навіть чисто емоційна відданість певному порядку (афективність діяння), а також упевненість у його незаперечності як утіленні безумовних цінностей не убезпечує від хиткості атитюдів. Як наслідок, для такої людини “перфоманси персуазивної комунікації” не спрацьовують, а лише посилюють недовіру. "На моє переконання, - зазначає М. Нанн, - комунікація - це наука і мистецтво, що набуває рис театру. За двадцять років, що я працюю в Україні, мабуть, найчастіше я стикався з комунікацією як театральним дійством. На мою думку, сьогодні в практиці впровадження комунікації українських органів влади бракує наукових підходів й методичного забезпечення" [5, с. 37].

Згідно з ідеями Т. Парсонса, “суспільство являє собою соціальну систему, яка визначається відносною самодостатністю з точки зору критеріїв рівноваги між такими факторами, як територіально орієнтована політична організація, доступ до економічних ресурсів, відтворення й соціалізація населення і культурна легітимізація системи як незалежного цілого. У кінцевому підсумку легітимізація вивищується до релігійних обгрунтувань, але в складних суспільствах, крім релігійного, існує і багато інших нижчеположних рівнів узаконювання" [10, p. 268].

Так само, як і щаблі влади, у структурі держави формується центральна культурна система, яка рано чи пізно стає носієм базових засад культури нації як такої. Остап Дроздов, ведучий ток-шоу "Drozdov" на телеканалі "ZIK", резюмує: "I цей політичний сезон, і минулий, i наступний я сприймаю як іще один віраж у реальності, яка в постмодерні зветься симулякром. Нам здається, що країна живе, що в ній щось робиться - погане чи добре, що життя в країні йде вперед, але все це глобальна омана. Політичне життя $\epsilon$ фейком. Політики вдають, що вони існують, а народ вдає, що цього не бачить" [2].

Дані досліджень громадської думки щодо вибору майбутнього шляху розвитку України та ії суспільного устрою свідчать про проблематичність формування загальнонаціональної ідеї на грунті ідеологічних засад. Таким чином, політичним партіям тут "нічого не світить", адже аморфність громадської думки через відсутність протягом тривалого часу (більше як 10 років) будь-якої ідеології, - тим більше для народу посттоталітарної країни, свідомість якого призвичаїлася до визначеності “правил гри” в ідеологічній сфері, - 3 певною необхідністю призведе 
до появи і підтримки заходів влади, схожих саме на тоталітарні “правила гри” (у даному разі це буде “диктатура олігархів" або якихось кланів владної верхівки). За цих умов найбільш вигідним для влади стає "розмноження" політичних партій, розпорошення і дублювання ідей та програм тощо. На думку М. Ожевана, "не підлягає сумніву, що громадянське суспільство для того, щоб протидіяти маніпулятивним впливам мас-медіа, має чинити спротив будь-яким спробам "медіатизації” та технологізації політики, носіями яких зазвичай $є$ “експерти” маніпулятивного типу, які намагаються накинути суспільству фрейми й порядок денний обговорення певних суспільно значущих проблем" [6, с. 121].

Питання свободи слова і вільних засобів масової комунікації завжди були в полі зору соціологів мас-медіа. Ідентифікація поля "вільної журналістики" є також складовою процесу легітимації власної ідентичності громадянина України. Забезпечення існування вільного інформаційного простору в Україні, виконання і дотримання вже чинних у цій сфері законів, їх доопрацювання і вироблення нових (які б регламентували, діяли, захищали право громадянина на інформацію і санкціонували покарання тих, хто перешкоджає цьому) - усе це могло б стати запорукою запобігання абсолютизації влади та поверненню України назад, до тоталітаризації суспільства, втраті нею державності. В умовах існування перерахованих загроз стає більш значущим і процес реконструкції ідентичності, тобто самовизначення особистості в межах певного статусу та відповідного рольового набору. Найбільш яскраво це відбивається у відтворенні “фреймів” рольової поведінки політиків, наприклад “електорального”, представленого аудиторії виборців або телеаудиторії під час виступу на телебаченні.

У зв'язку 3 вищесказаним цікавими видаються результати експертного опитування журналістів - членів НСЖУ $(\mathrm{N}=120)$ у липнісерпні 2017 р. (рис.). Дослідження проводилося під керівництвом автора статті. Контрольний масив склали 120 експертних анкет членів НСЖУ. Опитування проводилося “он-лайн” (з використанням digital panel "Anketa.in.ua").

Як бачимо з рисунка, утиски щодо доступу журналістів до інформації хвилюють опитаних журналістів-експертів значно більше, ніж загальні питання дотримання свободи слова. В останньому вони скоріше покладаються на Національну спілку журналістів України - і не тільки як на професійну спілку, а насамперед орган захисту прав журналістів. Дослідження показало, що журналіст певною мірою завжди бачить себе “лідером думок”, а отже, ототожнює себе і свою роль у суспільстві із самими політиками. Раціоналізація журналістом своєї ролі в суспільстві це ще й усвідомлення ним своєї ідентичності як представника суспільно значущої професії. 


\section{Кореляції компетенцій НСЖУ щодо дотримання свободи слова}

та доступу журналістів до інформації

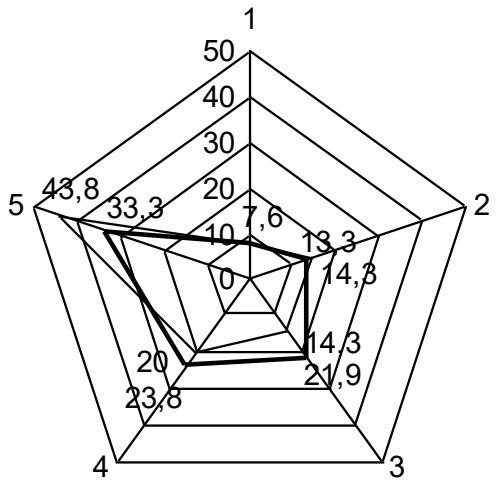

—— Коригування правових стандартів дотримання свободи слова Запобігання утисків та обмеження доступу журналістів до інформації

Рис. Можливості Національної спілки журналістів України щодо дотримання свободи слова та запобігання обмеженню доступу журналістів до інформації

Отже, можна констатувати (зокрема й з огляду на результати вищеартикульованого дослідження), що спільним для процесів реконструкції особистісної ідентичності як у журналіста, так і в політика $\epsilon$ наявність у них однієї з найважливіших рис - професійного ставлення до подій та явищ дійсності. Ця характеристика охоплює, зокрема, компетентність, упевненість, довіру, сталість, послідовність і контроль власних дій, відповідальність. Цей процес зазнає відчутного впливу не так з боку поточних подій, як від необхідності їх висвітлення в ЗМК. Таким чином, саме ЗМК $є$ тим деформувальним фактором, який однаково впливає на деформації ідентичності та в цілому особистісної сфери тих, хто професійно пов'язаний із сферою політики.

Відомо, що одним з найбільш важливих факторів, які зближують, консолідують людей, є спільні дії, особливо захист і спротив загрозі. Це забезпечує не тільки єдність зусиль у досягненні цілей, а й висуває 3 колективу (який створюється під впливом тих або тих обставин, що вимагають спільних зусиль) лідера - людину, яка спроможна витримати конкуренцію з іншими, виграти змагання. Водночас виникає необхідність (а не притаманна лідерові властивість, як модно нині писати в різноманітних іміджмейкерских “есе") брати на себе відповідальність за важливі рішення, командувати, якщо не напряму - але все ж нав'язувати 
свою волю, частіше - свою думку, свої міркування, переконання для досягнення усвідомлених цілей, намагань, намірів. Сукупність останніх і визначає той самий рівень домагань, який становить підгрунтя лідерського типу особистості.

У формуванні такого психокомунікативного типу, як лідерський, найбільшу роль відіграють певні потреби:

а) потреба в спілкуванні, володінні комунікативними техніками;

б) потреба бути визнаним, потреба в позитивному сприйнятті (адже негативне сприйняття така особистість розцінює як несправедливе);

в) потреба у схваленні своїх позицій, думок, міркувань, переконань.

Сама процедура реконструкції ідентичності особи лідерського типу має певні особливості. Тут ідеться насамперед про “укорінення" особистісних структур, їхню глибину і сталість, про наявність ефективних комунікативних зв'язків та стійкість перед зовнішнім тиском. Підгрунтям такої стійкості $є$ те, що особистість має глибоке коріння ідентичності, яке зберігає надійний зв'язок із сутнісними пластами “Я”. Особливу роль відіграють наявність і чіткість внутрішніх пріоритетів і водночас поступливість у непринципових моментах. Таку людину важче відволікти від головної мети або переключити на вирішення другорядних питань, iii не так просто перевести в таку площину дискусії, де було б легше спрямувати на неї маніпулятивний вплив.

Висновки. Реконструкція ідентичності - не тільки суттєвий важіль запобігання маніпулятивним впливам у різноманітних комунікативних ситуаціях, у тому числі гібридним впливам мас-медійного простору, а й свідчення реальної можливості шляхом такого реконструювання ідентичності відтворити самоповагу особистості та сприяти ії самовизначенню. Специфічні елементи процедури реконструкції ідентичності спрощуються певною мірою в особі лідера й можуть бути запозиченими для тренінгової роботи, зокрема психологічної розбудови усталеного особистісного “каркасу” нелідерського типу, але при цьому у звичайної людини напрацьовуються такі комунікативні компетенції, які дають їй змогу зберігати всі ознаки поглибленої особис-тісної ідентичності.

\section{Лimepamypa}

1. Александер Дж. После неофункционализма: деятельность, культура и гражданское общество / Дж. Александер ; пер с англ. Т. В. Дорофеевой // Социология на пороге XXI века. Основные направления исследований. Москва : Русаки, 1999. - С. 186-205.

2. Інтерв'ю з Остапом Дроздовим [Електронний ресурс] // Детектор медіа. Режим доступу : http://detector.media/community/article/128867/2017-08-14klitka-vidchinilasya-televeduchi-pidveli-pidsumki-politichnogo-sezonu-...

3. Інтерв'ю з Романом Чайкою [Електронний ресурс] // Детектор медіа. Режим доступу : http://detector.media/community/article/128867/2017-08-14klitka-vidchinilasya-televeduchi-pidveli-pidsumki-politichnogo-sezonu-... 
4. Луман Н. Реальность массмедиа / Н. Луман ; пер. с нем. А. Ю. Антоновского. - Москва : Праксис, 2005. - 256 с.

5. Нанн М. Реформа комунікацій органів влади як стратегічна потреба українського суспільства / М. Нанн // Запровадження комунікації органів державної влади: виклики та завдання : зб. матеріалів наук.-практ. конф. Київ : Фенікс, 2016. - С. 57-60.

6. Ожеван $M$. Маніпулятивні та контрманіпулятивні стратегії застосування експертно-медійних мереж у державних комунікаціях / М. Ожеван // Запровадження комунікації органів державної влади: виклики та завдання : зб. матеріалів наук.-практ. конф. - Київ : Фенікс, 2016. - С. 112-121.

7. Сусська О.О. Легітимація національної ідентичності як соціальна та соціально-психологічна проблема / О. О. Сусська // Культура і сучасність : альманах. - Київ, 2000. - № 1. - С. 98-116.

8. Сусська О. О. Трансформації комунікативних взаємин у світлі нових підходів до вивчення змін у мас-медійному просторі / О. О. Сусська // Проблеми політичної психології : зб. наук. праць / Асоц. політ. психологів України, Ін-т соц. та політ. психології НАПН України. - Київ : Міленіум, 2014. - Вип. 1 (15). - С. 313-323.

9. Habermas J. Theorie des kommunikativen Handelns. B. 2. Zur Kritik der funktionalistischen Vernunft / Jurgen Habermas. - Frankfurt fn Main, 1981. $184 \mathrm{p}$.

10. Parsons T. Social Systems and the Evolution of Action Theory / Talcott Parsons. - New York : Free Press, 1977.

\section{References}

1. Aleksander, Dzh. (1999). Posle neofunktsionalizma: deyatelnost, kultura i hrazhdanskoye obshchestvo [After neofunctionalism: activity, culture]. Translation by T. V. Dorofeeva. Sotsiologiya na poroge XXI veka. Osnovnyye napravleniya issledovaniy [Sociology on the threshold of the XXI century. Main directions of research] (pp. 186-205). Moscow: Rusaki Publ. (rus).

2. Interviu $\mathrm{z}$ Ostapom Drozdovym [Aninterview with Ostap Drozdov]. In Detektor media, http://detector.media/community/article/128867/2017-08-14klitka-vidchinilasya-televeduchi-pidveli-pidsumki-politichnogo-sezonu-...

3. Interviu z Romanom Chaikoiu [Aninterview with Roman Chaika]. In Detektor media, http://detector.media/community/article/128867/2017-08-14-klitkavidchinilasya-televeduchi-pidveli-pidsumki-politichnogo-sezonu-...

4. Luhmann, N. (2005). Realnost massmedia [Media reality]. Translatin by A. Yu. Antonovsky. Moscow: Praksis Publ. (rus).

5. Nann, M. (2016). Reforma komunikatsii orhaniv vlady yak stratehichna potreba ukrainskoho suspilstva [Reform of government communicatios as a strategic need of Ukrainian society]. Zaprovadzhennia komunikatsii orhaniv derzhavnoi vlady: vyklyky ta zavdannia: Zbirnyk materialiv naukovo-praktychnoi konferentsii [Implementation of communication of public authorities: challenges and tasks: Acollection of materials of the scientific-practical conference] (pp. 5760). Kyiv: Feniks Publ. (ukr).

6. Ozhevan, M. (2016). Manipuliatyvni ta kontrmanipuliatyvni stratehii zastosuvannia ekspertno-mediinykh merezh u derzhavnykh komunikatsiiakh [Manipulative and counter-manipulative strategies for applying expert-media 
networks in state communications]. Zaprovadzhennia komunikatsii orhaniv derzhavnoi vlady: vyklyky ta zavdannya: Zbirnyk materialiv naukovo-praktychnoi konferentsii [Implementation of communication of public authorities: challenges and tasks: Acollection of materials of the scientific-practical conference] (pp. 112-121). Kyiv: Feniks Publ. (ukr).

7. Susska, O. O. (2000). Lehitymatsiia natsionalnoi identychnosti yak sotsialna ta sotsialno-psykholohichna problema [Legitimization of national identity as a sotcial and socio-psychological problem]. Kultura $i$ suchasnist: Almanakh [Culture and modernity: almanac] 1, 98-116 (ukr).

8. Susska, O. O. (2014). Transformatsii komunikatyvnykh vzaiemyn u svitli novykh pidkhodiv do vyvchennia zmin u mas-mediinomu prostori [Transformation of communicative relations in the context of new approaches to the study of changes in mass media]. Problemy politychnoi psykholohii [Problems of Political Psychology], 1 (15), 313-323 (ukr).

9. Habermas, J. (1981). Theorie des kommunikativen Handelns. B.2. Zur Kritik der funktionalistischen Vernunft. Frankfurt am Main (germ).

10. Parsons, T. (1977). Social Systems and the Evolution of Action Theory. New York, Free Press.

\section{Susska O. O. Reconstruction of Personal Identity in Processes of Information Exchange in Conditions of Social Transformations}

It is upheld the opinion that in the environment of modern processes that influence the definition of personal identity, the space of mass communication has a great deal of importance. Attention is drawn to the fact that in this space the place of printed media gradually takes the Internet, and a radio and television, which by the influences on the circle of communication and the spiritual world of a human still occupy the first places, but significantly change their methods and means of influence. It is ratified that effective communicational relationships help to significantly counteract the external pressure: precisely because of the deep rooted identity, a person maintains a reliable connection between the essential layers of own "Self". It is emphasized that the very nature of communication and its development largely depend on the interests of the individual and those informational needs that satisfy the content of the mass media. It is also noted that no less important role in this process is played by the human awareness of personal identity and by the level of culture of mass communication products consumption.

Key words: personality, identity, mass media, information space, psychological qualities, transformation.

(с) Сусська О. О. 